\title{
Obadiah Sforno and the Individual Human Soul $^{1}$
}

The philosophical activity of Obadiah Sforno, who is primarily known for his exegetical interpretations of the Holy Scriptures, has received little scholarly attention. Nonetheless, the few scholars interested in Light of the Nations-Sforno's (uniquely) philosophical work-were particularly critical of the author's position in this exposition, showing a sceptical attitude towards the uniqueness of the work.

Obadiah Sforno's philosophical treatise reproduces the classical schema of the medieval quaestio disputata ("disputed question"), in which there was no place for a "new" or "innovative" analysis characterising some of the most original interpreters of the Renaissance period. He published the Hebrew version of Light of the Nations, entitled Or 'Ammim, in Bologna in 1537. In 1548, also in Bologna, he published the Latin version, with the title Lumen Gentium. The fact that Sforno himself translated his own work from Hebrew into Latin makes him particularly exceptional. ${ }^{2}$

The Hebrew and Latin versions do not appear to offer significant differences in their overall view. The order of the questions and the general approaches to each argument are identical (with very few exceptions), but nonetheless, we find several changes concerning the style and the breadth of topics, as will be clear from reading the passages presented in this paper.

Although the structure of Light of the Nations reproduces the medieval format of the disputed question, it seems that Sforno exercises a sceptical approach towards introducing the quaestio and establishing the solution. In Lumen Gentium, every question is preceded by dubitatur utrum ("it is questionable"), and in the last part -namely, the solution-of both versions, we read:

Ad dubium ergo respondetur

נשיב אם כן להתיר ספק החקירה הנזכרת

To dispel any doubt

Doubt does not only play a dialectical function in this pamphlet. Sforno is following the Maimonidean tradition, ${ }^{3}$ and he introduces "doubt and perplexity," which are

1 I would like to thank Professor Warren Zev Harvey for his advice, his valuable comments, and his suggestions on how to improve this article.

2 I will employ the appellation Light of the Nations to refer to both versions of the pamphlet in general terms; when appropriate, I will make a distinction between the Hebrew and Latin editions. 3 Cf. Warren Zev Harvey, "Maimonides' First Commandment, Physics, and Doubt," in Hazon Nahum: Studies in Jewish Law, Thought, and History Presented to Dr. Norman Lamm, ed. Yaakov Elman and Jeffrey S. Gurock (New York: Michael Scharf Publication Trust of the Yeshiva University Press; Hoboken, NJ: Ktav, 1997), 149-62.

2 OpenAccess. (c) 2020 Giada Coppola, published by De Gruyter. (cc))BY-NC-ND This work is licensed under the Creative Commons Attribution-NonCommercial-NoDerivatives 4.0 License. 
inherent in the quest for knowledge. Nevertheless, Sforno introduces the term safeq to present the solutions to the questions, in which sense the doubt is a synonym of "objection" (with reference to the previous arguments), following Gersonides, who was the first to use it in this manner. In the Renaissance, Isaac Abravanel employed safeq to translate obiectio in his Roš Amanah, confirming its double function, as did David Messer Leon in his Tehillah le-Dawid. For this reason, the relationship to Jewish scepticism cannot be ruled out, as is also highlighted by Giuseppe Veltri in his book Alienated Wisdom. ${ }^{5}$

Two articles by Robert Bonfil on Sforno's Light of the Nations appeared in 1976 and 1995 respectively. ${ }^{6}$ Both focused on the interpretation of the idea of the soul (the crucial points of which I will analyse in detail later). Bonfil highlights the lack of originality in the author's approach to philosophy; he considers Sforno not only a "terrible" philosopher-in comparison with his contemporaries, taking into account the brilliant work of Leone Ebreo-but also a woeful interpreter of the classical philosophical tradition. ${ }^{7}$ As Warren Zev Harvey has emphasised, a comparison between Leone Ebreo and Sforno turns out to be inappropriate, as the first was a great philosopher, while Sforno was an erudite scholar. Nevertheless, Bonfil recognises a "modern approach" represented by the relevance of the topic of the soul in Sforno's work, as the question of the immortality of the soul was one of the most common issues discussed in philosophical treatises during the Renaissance period. ${ }^{8}$

4 Harvey, 161.

5 Giuseppe Veltri, Alienated Wisdom: Enquiry into Jewish Philosophy and Scepticism (Berlin and Boston: De Gruyter, 2018), 143-44: "The sixteenth and seventeenth centuries are foundational for several aspects connected both with the Jewish consciousness of and attitudes towards scepticism. At the end of the Humanist period and the Renaissance, we can observe the first changes in the perception and formulation of philosophical questions. After some seminal beginnings, mirrored by 'Ovadya Sforno, there could be no hesitation in recognising that the use of dubitatur/dubium and quaestiones dubitatae is more than a rhetorical tool. They became a dialectical strategy that played an important role in the Late Renaissance (Accademia dei Dubbiosi) and early modern period (Accademia degli Incogniti, Simone Luzzatto). The 'doubts' (dubitationes) are not primarily a literary instrument to introduce the dogmatic opinion of teachers, masters, or opponents, but a dialectical strategy to introduce very delicate questions that could have dangerous results for the majority. The topics handled involve the usual themes of sceptic origins and tradition: authority, morality, theodicy, collective society and individuality, immortality of the soul as a social and moral problem (doctrine of remunerations), etc." 6 Robert Bonfil, "The Doctrine of the Soul and Holiness in the Teachings of Obadia Sforno" [Hebrew], Eshel Beer Sheva 1 (1976): 200-257; Bonfil "Il Rinascimento: la produzione esegetica di 'O. Servadio Sforno," in La lettura ebraica delle Scritture, ed. Sergio J. Sierra (Bologna: EDB, 1995), 261-67.

7 Bonfil, 270: "Non dovrebbe far meraviglia che non lo si sia preso sul serio e che, come filosofo, a lungo andare egli sia stato condannato al dimenticatoio."

8 Bonfil, 271: "Eppure, anche nella forma nella quale si presentava, il Lumen Gentium offriva un curioso esempio di elementi decisamente innovatore innestati sulla struttura essenzialmente medievale. Se, infatti, al di là dell'elenco delle quaestiones disputate, riflettiamo sulla quantità di energia discorsiva e conseguentemente sulla quantità di spazio dedicata ad ognuna di quelle questioni, ci si accorge subito che l'interesse era decisamente spostato su quanto era di attualitá nel Rinascimento, e in particolare sulla questione dell‘anima umana etc.” 
Apparently, Sforno's intention, as the author himself announces in the prologue of both treatises, was to refute some of the Aristotelian positions which were entirely at odds with the principles of the Jewish faith. Hence, the subtitle of Lumen Gentium is worthy of note: in it, Sforno expressly asserts that the book was written "against some opinions of Aristotle," and that it "demonstrates the doctrines of the creation of the universe from nothing, the providence God has for human beings, and the immortality of human soul, which they [i.e., Aristotelian philosophers] shamefully reject, deriding religion."

Charles Manekin follows the pattern established by Professor Bonfil, albeit with a less critical approach: "Yet it is also an attack on those principles of Aristotelianism that conflict with religious dogma, placing Sforno in the intellectually awkward position of appealing to Aristotle in order to undermine his own philosophy!"10 In fact, it may be better to state "appealing to the authority of Aristotle and Averroes in order to undermine their own philosophy." However, in my opinion, Sforno's particular approach represents a component of modernity, consisting of quoting a sentence not only for the argument, but also for the counterargument, which is the confutation of the topic presented in the first part of the quaestio. It is necessary to note that most of the quotations from Aristotle and Averroes in Light of the Nations are favourable and not critical, despite what was announced by the author himself. Sforno does not care about the principle of contradiction, according to which it is not possible that $p$ and - $p$ may be presented by the same authority; in this sense, he is not anchored in the classical medieval system.

Sforno was defined by the late Mauro Zonta as the last representative of what may be called "Hebrew Scholasticism," but also as an "anti-philosopher," as he characterised him in his contribution to the first international symposium on Obadiah Sforno. ${ }^{12}$ Taking into account the latest discoveries of the DFG-funded Sforno

9 Obadiah Sforno, Lumen Gentium (Bologna, 1548); frontispiece: "Opusculum nuper editum contra nonnullas Peripateticorum opiniones demonstratiue docens presertim circa creationem et vniuersi nouitatem et diuinam de mortalibus curam et humanarum animarum immortalitatem, quas ipsi turpiter respuunt religionis penitus irridentes quare illud merito Lumen Gentium appello."

10 Charles Manekin, in The Jewish Philosophy Reader, ed. Daniel H. Frank, Oliver Leaman, and Charles H. Manekin (New York: Routledge, 2000), 284.

11 Mauro Zonta, "The Autumn of Medieval Jewish Philosophy: Latin Scholasticism in 15th-Century Hebrew Philosophical Literature," in Herbst des Mittelalters? Fragen zur Bewertung des 14. und 15. Jahrhunderts, ed. Jan Aertsen and Martin Pickavé (Berlin and New York: De Gruyter, 2004), 475: "In Italy, there is evidence of the persistence of an interest in Latin Scholasticism by some Jewish philosophers active in the 16th century, e.g. Obadiah Sforno"; Zonta, Hebrew Scholasticism in the Fifteenth Century. A History and Source Book (Dordrecht: Springer, 2006), 30.

12 This symposium, entitled "Lost and Found in Translation-Ovadiah Sforno and His World," took place in Hamburg on 18 and 19 January 2017. In his paper entitled "Or 'Ammim/Lumen Gentium and the quaestio disputata," Zonta stated: "Ovadiah Sforno is therefore not seen today as a simple 'philosopher' but rather as an 'anti-Aristotelian' thinker, and so, considering the key role played by Aristotle in the thinking of that time, almost as a sort of 'anti-philosopher." Zonta was probably follow- 
Project at Hamburg University, as well as the studies of Giuseppe Veltri ${ }^{13}$ and Warren Zev Harvey, ${ }^{14}$ it is now possible to newly place Sforno in the history of Jewish thought: he may be defined not only as the last interpreter of Scholasticism, but also as the last Averroist. As Veltri phrased it, Sforno is "an Averroist malgré lui." Harvey, during his fellowship at MCAS, proposed an enlightening explanation: that Light of the Nations is the result of Sforno having taught classes in Latin on Averroist philosophy. Sforno was presumably hired to teach this class by the professors at Bologna University, or perhaps by Christian theologians. In this sense, Averroes represents not only an "authority" in Sforno's treatise, but also the subject matter of his teaching. As Harvey suggests, Sforno could have been moved to teach the Christian scholars in Bologna about Averroes for the same reason he chose to teach Reuchlin Hebrew in Rome.

This general overview paves the way for new perspectives: Elijah del Medigo (1458-93) - who was most active in Padua and Venice-would no longer be held as the last "Averroist" 15 of the Jewish tradition, since Averroes would have continued to have been studied in Jewish communities into the sixteenth century. As Montada noted, this tendency persisted in the Latin world-with its ups and downs-until the Renaissance period. A similar phenomenon may be observed in Jewish thought: "Jewish Averroism" is a concept that usually refers to Jewish philosophers who philosophised within the context of Averroes's interpretation of Aristotelian philosophy. For this reason, Sforno should be considered as a Jewish Averroist; chronologically speaking, as the last one. The fact that Sforno does not conform to all of Averroes's philosophy is not an indication of an anti-Averroistic attitude.

Even though Bonfil and Manekin note the influence of Averroes throughout Sforno's work, they do not stress the importance of this aspect, not remotely considering the general overview of the Italian setting. ${ }^{16}$ On the contrary, for them, the impor-

ing the interpretation of Cecil Roth in his The Jews in the Renaissance (Philadelphia: Jewish Publication Society, 1959), 80-81.

13 Veltri, Alienated Wisdom, 162-67.

14 The second international symposium on Obadiah Sforno and his world, entitled "The Philosophical Canon of Obadiah Sforno and His Contemporaries," took place in Hamburg on 5 and 6 November 2018.

15 Josep Puig Montada, "Eliahu del Medigo, the Last Averroist," in Exchange and Transmission across Cultural Boundaries: Philosophy, Mysticism and Science in the Mediterranean World, ed. Haggai Ben-Shammai, Shaul Shaked, and Sarah Stroumsa (Jerusalem: Israel Academy of Sciences and Humanities, 2013), 155-86.

16 Bonfil, "Il Rinascimento," 266: "Il metodo del ragionamento ello Sforno resta dunque ancorato alla pesante dotta struttura accademica che ci si accorge poi subito essere costruita tutta di "mattoni" di auctoritates phylosophorum, prima tra i quali naturalmente Aristotele e Avveroè. Insomma, dichiarando in cima all'opera latina, che l'intento era disputare con nonnullas Peripateticorum opiniones, lo Sforno non intendeva affatto respingere il discorso peripatetico, bensì precisamente inserirsi organicamente in esso, prendere parte in una discussione considerata attualmente in corso, sempre valida"; 269: "Questo sistema aristotelico-averroistico [...] costituiva la struttura di riferimento del pensiero medievale di tutti, ebrei e cristiani Esso era ancora al centro della discussione filosifica nelle 
tance accorded to Averroes corroborates the idea that Sforno was anchored to an outdated medieval tradition. In the Italian universities and in academic environments, Averroes was still being studied and commented on by scholars and members of the intellectual community. Since the lack of new elements in Sforno's treatise, such as (Neo-)Platonism and Kabbalah, has been considered a negative factor up until now, in view of recent studies, is it possible to suppose that Sforno's intention was to become a "full" member of an élite and to be accepted by the Italian university milieu?

It is likely that Light of the Nations was written for a particular audience (Christian and academic) and this could also explain Sforno's modus operandi, according to which only Aristotle and Averroes are quoted, since they are still considered the major “authorities" for systematic philosophical thought. Sforno's interpretation and exposition of Aristotelian philosophy is highly complex and sophisticated; it is not only based on medieval Scholastic sources, such as Aquinas, Grosseteste, and Jandun, but also on contemporary ones, among them Paul of Venice, Gaetano da Thiene, and Augustine Nifo; namely, the representative figures of the "strong" Averroeian tradition. This is the tradition according to which Giglioni identifies the Averroistic tendency in European culture. ${ }^{17}$ Sforno belongs to this trend, all the more so given that he decided to write his work in both languages for two different audiences.

This point also characterises Sforno's general attitude towards philosophy, which is embedded in his deliberate choice to refer only to Averroes throughout the entire Light of the Nations, with the exception of Maimonides, who is mentioned twice in Or 'Ammim. ${ }^{18}$ Moreover, another particular aspect-which has been neglected by scholars-is the use of Latin sources in the Hebrew version as well: Sforno does not employ the Hebrew translations of Averroes, but only the Latin editions, ${ }^{19}$ and this is very surprising since all the texts were available in Hebrew translation.

universitá d'Italia durante il Quattrocento e gran parte del Cinquecento. Sennonché in questo periodo operavano sul sistema medesimo le tendenze caratteristiche dell'umanesimo e del rinascimento, rendendo possibile l'introduzioone in esso di componenti eclettiche, soprattutto platoniche, che finirono per trasformarlo più o meno radicalmente. Orbene, contrariamente a quanto si puó tuttora leggere qua e là neo manuali di storia degli ebrei nel Rinascimento, il Lumen Gentium restó fondamentalmente fedele al sistema aristotelico-averrostico.”

17 Cf. Guido Giglioni, "Introduction," in Renaissance Averroism and Its Aftermath: Arabic Philosophy in Early Modern Europe, ed. Anna Akasoy and Guido Giglioni (Dordrecht: Springer, 2013), 2. “"Averroistic' refers to the generic cultural label denoting a pronounced rationalistic attitude, of a vaguely Aristotelian ilk, towards questions of philosophical psychology (in particular, the nature of the human mind and its survival after the death of the body), natural determinism and, above all, the relationships between philosophical freedom and dogmatic truths, often of a religious kind."

18 Obadiah Sforno, Or 'Ammim (Bologna, 1537), 8, 10.

19 A clear example is given by the employment of the expression "contra Garicone" (נגד גאריקו) to indicate the Megarians in book Theta of Metaphysics, a misunderstanding which is only found in the Michael Scotus edition, which was published in Venice in 1473. 
Sforno's erudition is nevertheless evident throughout, displayed in his use of Jewish, Arabic and Scholastic sources, which he cleverly disguises, as there is no mention of them in his treatise. His philosophical knowledge is quite clear when we compare the pamphlet with the exegetical and biblical commentary. An evident example is represented by his interpretation of Numbers $7: 89,{ }^{20}$ in which he interprets מדבר (vocalised middabber) as God speaking to Himself, which is clearly a reference to the theory of the intellect in Maimonides's Guide of the Perplexed 1:68. However, Sforno does not mention this biblical verse in his Light of the Nations, even if he presents a similar argument in the sixth question, "On the Creation," according to Maimonidean principles. As Rabbi Kravetz supposes, the commentaries are chronologically later than $\mathrm{Or}$ 'Ammim.

Sforno considers the relation between reason and revelation as an essential point in order to understand the ultimate goal of human beings, which is naturally the higher knowledge of God. His attitude towards philosophy follows the classical Jewish tradition, according to which it is possible to find a standpoint to reconcile the claims of reason and revelation. Sforno criticises the Aristotelian principles that are contrary to the Torah. Nonetheless, he accepts twenty-seven "philosophical propositions" as being in accordance with the Torah's teachings. ${ }^{21}$

However, as his starting point for Light of the Nations, Sforno assumes that the root of every philosophical and scientific thought is founded in the Torah: Moses, during the revelation on Sinai, received the Torah that is not only the Law, but also the original wisdom. Light of the Nations sticks to this principle: in order to resolve the philosophical issues, the "final" solution Sforno presents is always characterised by the exegetical interpretation of a biblical passage.

\section{Sforno's Arguments regarding De Anima}

The problem of the human soul and its perfection occupies the third part of Light of the Nations, ${ }^{22}$ and, as mentioned above, it represents the most important section of

20 "And when Moses was gone into the tabernacle of the congregation to speak with Him, then he heard the voice of one speaking unto Him from off the mercy seat that was upon the ark of testimony, from between the two cherubims: and he spake unto Him” (King James Version).

21 Cf. Or 'Ammim, 12-14, and Lumen Gentium, 9-11.

22 Summarising the topics of Light of the Nations, we can divide the work into three different sections. In the first part of the book-chapters 1-7-Sforno analyses the physical cosmos, denying any possibility of the pre-eternity of the sublunary and superlunary worlds with particular attention to some topics such as the movement of coming-to-be and passing away, the elements, prime matter, the heavens, and motion. In the second part-chapters 8-10-he analyses the metaphysical and ontological aspects, the nature of God, unicity, corporeality, knowledge, and God's will. In chapters 1114, the author approaches some questions on the soul, the nature of the soul, the morality of man, and providence. Chapter 15 could be considered a sort of "outsider" on account of its principal argu- 
Sforno's enquiry. Sforno demonstrates the immortality of the human soul and its incorruptibility by refuting four arguments, which are founded upon Averroes's Long Commentaries on Aristotle and the Incoherence of the Incoherence. ${ }^{23}$

Bonfil specifically criticises Sforno's approach to the question of the soul, which he considered to be an obsolete approach commonly found in the classical medieval Judeo-Christian tradition that was closed to the new influences typical of this era. ${ }^{24}$ Sforno "saves" some principles of the Averroeian/Aristotelian system (the twentyseven propositions presented at the beginning of Light of the Nations) which are in accordance with Jewish religious dogmas. Hence, Bonfil asserts that Sforno may be compared with "some thinkers [who are] supposed to be paradigmatic followers of Averroes without believing in the Averroeian doctrines," as Pomponazzi phrased it. $^{25}$

At the beginning of chapter 12, the reader is faced with the first problem, which constitutes the heart of the question:

אם הנפש האנושית השכלית אשר בה היה האדם מדבר qua substantialiter dicitur rationalis בעצם היא בלתי נפסדת אם אית השית אשר sit quid immortale vel non.

Whether the intellectual human Whether the intellectual human soul, by which soul, by which man it is essentially man is essentially rational, is incorruptible or called rational, is immortal or not. not.

ment, which includes and embraces all those three aspects-physics, metaphysics, and providencewith particular focus on the relationships between deity, essence, and humankind.

23 The primarily sources are the Long Commentaries on On the Soul 3.5, Book Lambda of Metaphysics, and On the Heavens, as well as the Incoherence of the Incoherence. As aforementioned, Sforno probably uses the Scot's version for the commentaries and for the original Averroes' works, he uses the Nifo's edition.

24 Bonfil, "Il Rinascimento," 269-70: "Lo sforzo precipuo del nostro viene quindi rivolto a correggere il sistema aristotelico-averroistico dal di dentro, a salvarlo dai propri errori e quindi anche dalle critiche che si sarebbero potute muovere ad esso. Non diversamente da consimili tentativi di pensatori cristiani, come per esempio Pietro Pomponazzi, lo Sforno intese salvare il principio averroistico dell'intelletto separato e eterno comune a tutto il genere umano senza peró rinunciare alla esigenza religiosa di credere nell'esestinza di un'anima individuale forma dell'uomo, sostanza separata e eterna, non pura potenzialità. Come Averroé, lo Sforno sosteneva che l'intelletto materiale non è neque corpus neque virtus in corpore. Secondo lui, però, l'anima umana è sostanza individuale, eterna, emanante da una non meglio definita essenza superiore.”

25 Bonfil, 270: "Con questa posizione di apertura, lo Sforno si allineava decisamente con quei pensatori che a detta di Pomponazzi si credevano di essere averroisti senza peraltro esserlo davvero." Cf. Bruno Nardi, Studi su Pietro Pomponazzi (Florence: Le Monnier, 1965), 18-19: "Ideo teneo quod orrupt Averrois devitat maiores difficultates quam alia; nec me pudet amore orruptio me ipsum retractare. Unde qui dicunt me aliis orruptio ut contradicam, mentiuntur. Oportet enim in philosophia haereticum esse, qui veritatem invenire cupit.” 
In Or 'Ammim, the statement of the problem focuses on the concept of the corruptibility of the soul (nifsad). In Lumen Gentium, we find the word "immortality" (immortale). The two ideas are naturally equivalent, because the notion of incorruptibility logically embraces the idea of immortality. Sforno uses the Hebrew term niṣhi to translate the Latin immortale, even if it literally signifies "eternal." Nevertheless, the author himself explains that nifsad and niṣhi and immortale and incorruptibile are synonyms. This kind of distinction is also presented by Thomas Aquinas, who, when alluding to Augustine in the Summa Theologiae, shows that some substances are incorruptible (incorruptibilis) and immortal (immortalis). ${ }^{26}$ In this example, it is interesting to note that the Hebrew 'eșem nivdal-literally, "separate substance"-is translated as abstractum from matter, which normally indicates the pure form (נבדל מן החומר).

Quodlibet abstractum est immortale

שכל עצם נבדל הוא נצחי28 sive incorruptibile. ${ }^{27}$

Every abstract substance is immortal Every separate substance is incorruptible. or incorruptible.

Sforno, in defence of the immortality of the soul, points out four essential arguments according to which he explains the nature of the (human) soul, from the general definition of the faculty to the particular characterisation of the intellectual human soul: - The (in)corruptibility of the soul (in $\mathrm{Or}^{\mathrm{C}} \mathrm{Ammim}^{29} /(\mathrm{im})$ mortality of the soul (in Lumen Gentium) ${ }^{30}$

26 Cf. Thomas Aquinas, Summa Theologiae 1.97.1: "Respondeo dicendum quod aliquid potest dici incorruptibile tripliciter. Uno modo, ex parte materiae, eo scilicet quod vel non habet materiam, sicut Angelus; vel habet materiam quae non est in potentia nisi ad unam formam, sicut corpus caeleste. Et hoc dicitur secundum naturam incorruptibile. Alio modo dicitur aliquid incorruptibile ex parte formae, quia scilicet rei corruptibili per naturam, inhaeret aliqua dispositio per quam totaliter a corruptione prohibetur. Et hoc dicitur incorruptibile secundum gloriam, quia, ut dicit Augustinus in epistola ad Dioscorum, tam potenti natura Deus fecit animam, ut ex eius beatitudine redundet in corpus plenitudo sanitatis, idest incorruptionis vigor. Tertio modo dicitur aliquid incorruptibile ex parte causae efficientis. Et hoc modo homo in statu innocentiae fuisset incorruptibilis et immortalis. Quia, ut Augustinus dicit in libro de quaest. Vet. Et Nov. Test., Deus hominem fecit, qui quandiu non peccaret, immortalitate vigeret, ut ipse sibi auctor esset aut ad vitam aut ad mortem. Non enim corpus eius erat indissolubile per aliquem immortalitatis vigorem in eo existentem; sed inerat animae vis quaedam supernaturaliter divinitus data, per quam poterat corpus ab omni corruptione praeservare, quandiu ipsa Deo subiecta mansisset. Quod rationabiliter factum est. Quia enim anima rationalis excedit proportionem corporalis materiae, ut supra dictum est. Conveniens fuit ut in principio ei virtus daretur, per quam corpus conservare posset supra naturam corporalis materiae.”

27 Lumen Gentium, 57v.

28 Or 'Ammim, 89.

29 Or 'Ammin, 84: שכל צורת נפסד היא אמנם נפסדת והנה הנפש האנושית השכלית היא צורת נפסד אם כן היא נפסדת 
- The nature of the intellectual human soul; i.e., whether each individual has their own soul or where there exists only one common soul for the entire human species. $^{31}$

- The potentiality of the intellectual human soul; $;^{32}$ namely, whether the intellect is a power of the soul.

- The perfection of the intellectual soul as the actualisation of the material intellect/the fallacy of the intellectual human soul.

The problem of the soul is presented together with another question intrinsically related to the last part of the argument Sforno presents in this chapter; namely, the perfection of the (human) soul. In this case as well, the Hebrew and Latin editions present some differences. The influence of Thomas Aquinas ${ }^{33}$ is manifest in Lumen Gentium: Sforno's interpretation is easy to understand, as he translates the expression השלמות השני with actum secundum, a term that Aquinas uses in his commentaries.

\section{Sforno's Solution: The Human Soul Is Emanated from a Spiritual Nature}

Sforno proposes a solution, in line with the classical Jewish tradition: the intellectual human soul is immortal (incorruptible and eternal) and individual. It is interesting to focus on his analysis, which is naturally founded upon the Aristotelian and Averroeian system, but also characterised by some original elements, especially in the Latin version:

Intellectiva hominis anima qua scilicet

הנפש האנושית השכלית אשר בה נאמר שהאדם

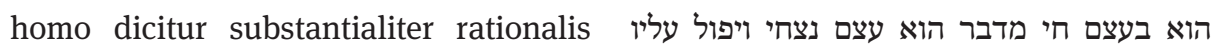
est quid immortale, ad individuorum nu- ריבוי כמספר אישי המין האנושי ומקורו מטבע העיפ עליו

\footnotetext{
30 Lumen Gentium, 55v: "Nulla mortalium forma est immortalis, intellectus hominis anima est huiusmodi, ergo non est immortalis."

31 Cf. Maimonides, Guide of the Perplexed, trans. Shlomo Pines (Chicago: Chicago University Press, 1963-78), 1:74 (seventh method).

32 Cf. Giovanni Pico della Mirandola, Conclusiones sive Theses DCCCC: Romae anno 1486 publice Disputandae, sed non admissae, ed. Bohdan Kieszkowski (Geneva: Droz, 1973), Conclusiones paradoxe numero LXXI. secundum opinionem propriam noua in philosophia dogmata inducentes: "Cuilibet seriei animarum unus correspondet purus intellectus."

33 Cf. Thomas Aquinas, De Anima II, lectio 4, 12, 14, 16; III, lectio 1, 2, 5-9, 11. Thomas Aquinas, Aristotle's De Anima in the Version of William of Moerbeke and the Commentary of St. Thomas Aquinas, trans. Kenelm Foster and Sylvester Humphries, repr. ed. (New Haven: Yale University Press, 1959). 34 Lumen Gentium, 58v.

35 Or 'Ammim, 92.
} 
merum dinumerabile, et hoc quia producitur a quadam spirituali natura a superis, sive abstractis intelligentiis emanante, quibus ipsa potentialiter inest, qui scilicet natura est humano generi communis prout videtur Aven R. de mente Philosophi inferred Metaphysicorum VII, 31 quod scilicet virtus intellectiva tanquam quid abstractus habet $\mathrm{ab}$ abstractio quodammodo produci. Et idem Platonis auctoritate infert Metaphysicorum XII, 18 ubi dicit: "Animam intellectivam fieri a Deis secundis” huiusmodi ergo nature proportio ad actuales hominum individuorum formas, talis est qualis est proportio materie prime ad actuales hominum individuorum subiecta. ${ }^{34}$

The intellectual human soul, by which man is essentially called rational, is immortal, and its plurality corresponds to the number of individuals because [the intellectual human soul] is produced by a spiritual nature emanating from the higher-namely, the separate intellects, in which it [the intellectual human soul] is found in potency, meaning that the nature [of the intellectual human
כוחיי משותף לכל המין האנושי שופע מנבדלים

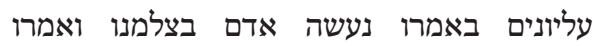

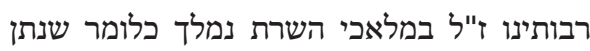

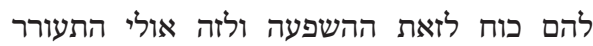

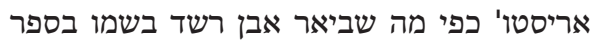

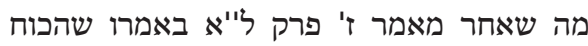
השכלי יתהוה מהנבדלים וכן ביאר בספר הנרי ליאר

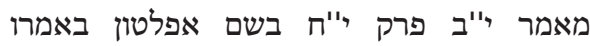
שהנפש האנושית נאצלת מן האלהים השניים באים באפון

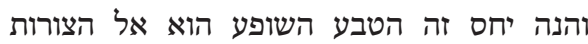

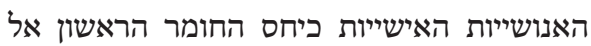
אישי נושאי המוחשות הנמצאים בפועל35 כיחס היחות
The intellectual human soul, by which it is said that man is essentially a rational living being, is an immortal substance and multiplicity is applicable to it, as is the number of the individuals of the human species. And [the intellectual soul] has its origin in the potential nature shared by the whole human species, which emanates from the higher separate [intellects], as it says [Genesis

36 Cf. Long Commentary on Metaphysics [1494 and 1497]; Averroes, Ibn Rushd's Metaphysics: A Translation with Introduction of Ibn Rushd's Commentary on Aristotle's Metaphysics, Book Lām, ed. Charles Genequand (Leiden: Brill 1984), 106: "This shows that these proportions are somehow inspired by a cause nobler, worthier and higher in rank than themselves, i.e. the world soul which Plato thought had been produced by the secondary gods and Aristotle by the sun and the ecliptic"; 108: "He also explained it here, saying that this soul is that postulated by Plato as being produced by the secondary gods and by Aristotle by the sun and the ecliptic. This question is extremely difficult and obscure and we shall explain it to the best of our abilities and according to the premises and principles which have been established, in our science by the doctrine of the man whose doctrine, in the words of Alexander, is the least subject to doubts, the most adequate to being, the most adapted and suited to it and the most free of contradictions."

37 Cf. Themistius, On Aristotle On the Soul, trans. Robert B. Todd (London: Bloomsbury, 2014), 20,19 paraphrasing Aristotle's On the Soul 407a2-11; p. 36; Plato, Timaeus 41a. Cf. Genequand, Ibn Rushd's Metaphysics, 106 n. 87. 
soul] is common to the whole human species, Averroes seems to explain in the name of the Philosopher in Metaphysics 7.31, saying that since the intellectual power of the soul is a separate substance, therefore it is produced by a separate intellect. This is similar to what Plato says in Metaphysics $12.18,{ }^{36}$ in which he states: "The intellectual soul comes from the secondary gods." 37 And therefore, the relationship of this nature to the form of the individual human being existing in act is like the relationship of the prime matter to the substrate of the individual human being existing in act.
1:26]: "We made man in our image." And our Masters, of good memory, said [Genesis Rabba 8:8]: "He consulted the ministering angels," that is to say that He provided them with the power for this emanation. And this, perhaps, Aristotle recognised, according to what Averroes explains quoting him in Metaphysics 7.31, that the intellectual power came to be from the separate [intellects]. And he also explains in the aforementioned book 12, par. 18, quoting Plato, that the lofty human soul is emanated from the secondary gods and [that] the relation of this emanating nature to the human individual souls was like the relation of prime matter to the individuals of the substrates of the sensible which exist in act.

The most obvious difference is related to the biblical and Talmudic references, which do not appear in the Latin version. While in Or 'Ammin, the higher and separate intellects may be identified with the angels, according to Sforno's interpretation of Genesis Rabba, in Lumen Gentium, the separate intellects are emanated from "indeterminate" natures called the "higher spiritual natures." Moreover, in the Jewish philosophical tradition, the connection between the separate intellects-which are also intelligencesand the angels had already been noted by Maimonides ${ }^{38}$ and Gersonides. ${ }^{39}$

A detailed explanation of the nature of the spiritual "substance" is given in the second counterargument, i.e., against the idea of the multiplicity of the soul. In that case, Sforno clearly states that the spiritual natures may be identified with Plato's secondary gods, mentioned by Averroes in his commentary on Metaphysics Lamb$d a{ }^{40}$ This tradition is a direct reference to Themistius's interpretation of the Aristo-

38 Cf. Maimonides, Guide of the Perplexed 2:4-6.

39 Cf. Gersonides, The Wars of the Lord, trans. Seymour Feldman (Philadelphia: Jewish Publication Society, 1999), 5:2: “Themistius, On Aristotle On the Soul which according to Plato is generated from the movers of the heavenly bodies, whereas according to Aristotle it is generated from the sun and the inclined sphere [i.e., the ecliptic]. Hence, the soul performs its operations accomplishing the [intended] goal, although not knowing the goal.” P. 87,

40 Cf. Yoav Meyrav, "Spontaneous Generation and Its Metaphysics in Themistius' Paraphrase of Aristotle's Metaphysics 12," in Aristotle Re-Interpreted. New Findings on Seven Hundred Years of the Ancient Commentators, ed. Richard Sorabji (London and New York: Bloomsbury Academic, 2016), 195-210. 
telian text. Sforno did not read Greek, and the Latin edition of Themistius's commentaries was printed after his death. We cannot rule out the possibility that he read the Hebrew translation of Themistius, but the most plausible source is Nifo, who uses Themistius and the other Greek commentators in his commentaries. ${ }^{41}$

Et tamen de ipsa spirituali natura quamvis antequam humano individuo copuletur habeat quodammodo esse scilicet potentiale, non tamen sequitur illa contradictionis implicatio, que sequitur ad sermonem dicentium ut detur materia prima existens a qualibet forma denudata, quia in quantum materia tantum est quid potentiale tantum, et pro quanto actu existeret esse quid actu ens quod implicat contradictionem sicut Aven R. docet in commento libro De Caelo III, 29 et quia ipsa intellectiva sive spiritualis natura a superis sive Deis secundis emanans, ut supra, non influitur ab eis actu nisi dato subiecto sibi proportionato et eiusdem capaci cuius sit actu forma, sicut accidit de lucido a quo non emanat actualis lux nisi dato diaphano eidem luci proportionate. Quare huiusmodi spiritualis natura habet suum potentiale esse in his secundis Deis antequam influant. Suum vero actuale esse acquirit postquam ab eis in subiecto sibi disposito influxa fuerit cum fiat actualis illius forma et per consequens plurificatur ad individuorum numerum ad quos emanare contingit. ${ }^{42}$

And although this spiritual nature, before being in conjunction with the human individuals, is something in potency, it [this idea] does not involve a contradiction. And by this discussion, it follows
אמנם עם היות זה הטבע נמצא קודם שישפע על המי החיר

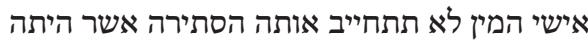

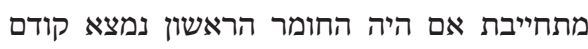
שתחול עליו צורה. וזה כי אמנם החומר הראשון

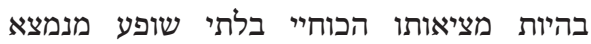

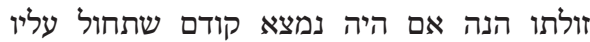
צורה היה מתחייב מזה שהיה לו מציאות בפועל.

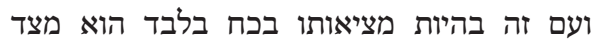

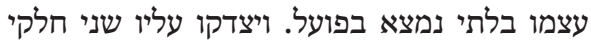

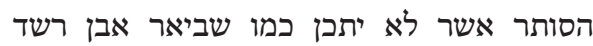

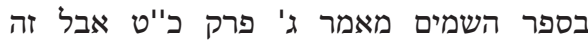
הטבע השכלי השופע מן השכלים ראוי שיה מיה ביה ביה לו מציאות כוחיי במשפיע קודם שישפע בעפע בפועל.

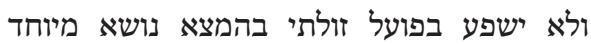

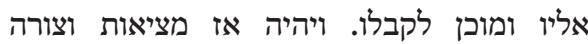

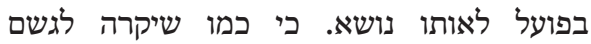

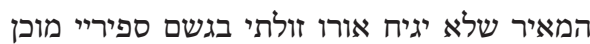

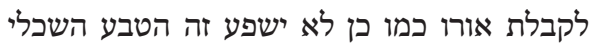

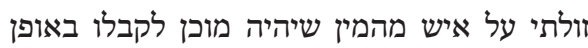

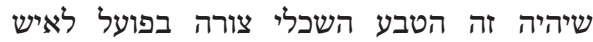

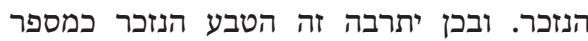

האישים אשר ישפע עליהם יתרבה זית

However, although this nature exists before it emanates on the individuals of the species, this does not have to mean that the contradictory exists which would be necessary if the first matter existed

41 Cf. Agostino Nifo, Commentationes in librum Averrois de Substantia Orbis (Venice, 1508), f. 2. 42 Lumen Gentium, 60r.

43 Or 'Ammim, 95. 
that there is prime matter devoid of form, because this matter is in potency only, and if existing in act is being in act, and this implies a contradiction, as Averroes explains in the commentary On the Heavens 3.29. And this is because the intellectual or spiritual nature is emanated from higher and secondary gods, as mentioned above. And it will only be emanated in act with the subject specified for it and disposed for it, and its form is in act because it will happen that a luminous body will emanate light in act only if there is a transparent body which is proportioned to its light. Likewise the intellectual nature, if it is in potency, will emanate before through the secondary gods; if it is in act it will receive things which have been emanated by the subject specified for it and it will produce a form in act and consequentially its plurality is the same as the number of individuals on which it will emanate. prior to the initiation of a form on it. And this is so because the first matter, since it exists in potency only, does not emanate from another existent. If this existent existed prior to the initiation of form on it, it would have to be the case therefore that it had a reality in act. And since its essence is in potency only, it-with regard to its substance-does not exist in act. And two parts of this contradiction would be proven for it, which is not possible, as Averroes explains in On the Heavens 3.29. But this intellectual nature which emanates from the intellects is suited for a potential existence in the emanator before it emanates in act. And it will only emanate in act (together) with the forth-bringing of a substrate specified for it and disposed for its reception, and then the reality and the form will be in act for that substrate. Because, just as it is the case that luminous body will not emit his light except through a transparent body which is disposed for the reception of his light, likewise this intellectual nature will only emanate on an individual of the species which is disposed for its reception in such a way that this intellectual nature will be a form in act for the aforementioned individual. And therefore, the aforementioned nature will become a plurality which matches the number of the individuals on which it will emanate.

However, the author clarifies in this passage that the expression spiritualis natura means intellectiva natura (השכלי הטבע). The term belongs to classical philosophical terminology; in the Italian Renaissance Jewish context, a similar phrase is presented 
by Leone Ebreo in Dialoghi d'amore, ${ }^{44}$ in which we also encounter the metaphor of the light and the transparent body. ${ }^{45}$

In Lumen Gentium, the correspondence between intellectual natures/secondary gods and angels is given a few lines later. Likewise, in the Platonic tradition, God orders the angels to create mortal beings:

"Et creavit Deus hominem ad imaginem "God makes man in our image, etc." Per-
suam etc." et fortasse hoc voluit Plato di- $\quad$ haps this is what Plato wants to attest

44 Leone Ebreo, Dialoghi d'amore di Maestro Leone Medico Hebreo (Roma: per Antonio Blado d'Assola, 1535), 169r: "Et tu non m'hai mostrato che l'intelletto humano qualche vota mene in tanta perfettione, che si puo sollevare a copularsi con l'intelletto divino, overo angelico separato da materia, e finirlo in atto vedendolo direttamente, e non per discorso potenztiale, ne mezzo corporeo." On the light cf. also 196v: "Ma questo è come vedere il lucido corpo del Sole in acqua, o in altro diafano; perchè la debile vista non può vedere de diretto in se stesso: che cosi il nostro intelletto humano nelle corporee vede l'incorporee." Cf. also Thomas Aquinas, Summa contra Gentiles 3.43 and Scriptum super Sententiis, lib. 2, d. 13, q. 1, a. 3.

45 This kind of metaphor was already familiar in the Scholastic milieu: cf. Robert Grosseteste, De Luce and Hexameron; Thomas Aquinas, Summa contra Gentiles 3.65.

46 Lumen Gentium, 62v, and cf. 62r-62v: "Et hec sapienter docet Sacrum Genesis documentum 1 cum dicit: 'Deum creasse hominem ad eiusdem imaginem quasi ad eius similitudinem' ubi per divinam imaginem intelligit intellectum quo intelligibilia imaginamur, quem dicit esse divine nature et per consequens est quid immortale, et cum hoc docet quod per eiusdem intellective nature cognitionem quam per suam propriam actionem percipimus, nonnullam de Deo nedum de reliquis abstractis possumus habere cognitionem, cum scilicet huiusmodi naturam Dei imaginem appellet, inferens quod sit quodammodo divine nature, ad quod sequitur ut per eiusdem intellective nature cognitionem ad aliqualem de Deo cognitionem pervenire possumus. Quare Aven R. in commento libro De Anima I, 2 ait: 'et debes scire que iuvamentum scientie de anima ad alias scientias invenitur tribus modis etc.' subdit ibidem dicens: 'divinus autem sive metaphysicum suscipit ab ea substantiam subiecti sui, hinc enim declaratur quoniam forme abstracte sunt intelligentes, et alia multa de cognitione dispositionum consequentium intelligentiam in eo quod est intelligentia et intellectus etc.' Et idem videtur inferre ibidem III, 5 ubi dicit: 'et nisi esset hoc genus entium quod scimus per scientiam anime non possemus intelligere multitudinem in rebus abstractis quemadmodum nisi sciremus naturam intellectus non possemus intelligere quod virtutes moventes debeant esse intellectus etc.' cumque prefatus Genesis textus ibidem scilicet circa humanam productionem tamen non autem circa reliquas dicat: 'et dixit Deus faciamus' quibus videbatur quodammodo angelos alloqui, docet quidem huiusmodi intellectivam naturam ab eisdem angelis Dei iussu emanare ut supra, et hoc quia tunc Deus dedit eis potentiam influendi huiusmodi naturam quam Dei imaginem appellat ab eodem Deo tunc creatam, quare sequitur dicens 'et creavit Deus hominem ad imaginem suam etc' et fortasse hoc voluit Plato dicens quod Deus iussit angelis ut crearent mortalia prout Aven R. refert in commento Metaphysicorum XII, 44. Cumque idem Genesis documentum ibidem dicat 'quasi ad similitudinem nostram' videtur inferre arbitrariam voluntatem, qua fit quodammodo Deo similis et angelis per quanto est agens cum cognitione, cuius oppositum accidit naturali agenti, similitudo enim per formam formam vero per actiones consideramus. Merito tamen ponitur ly quasi inferens quod non est omnimoda similitudo, ab angelis enim differt in suis actionibus quoad arbitrium, a Deo vero quo ad arbitrii nobilitatem. Quibus demonstrative docet eiusdem Dei imaginis immortalitatem, et hoc quia cum sit quid divine nature et per consequens presit corporeis etiam celestibus licet sint 
cens quod Deus iussit angelis ut crearent mortalia prout Aven R. refert in commento Metaphysicorum XII, $44 .{ }^{46}$ when he says that God ordered the angels to create the mortal beings, as Averroes reports in the commentary on Metaphysics 12.44 .

In the Hebrew edition, Sforno quotes verbatim the passage from the Long Commetary on Metaphysics ${ }^{47}$ in which Averroes mentions Plato's opinion according to which the creator created the angels himself. As Harvey also notes, this a good example of Sforno's skill as a biblical commentator. He gives new meaning to Genesis 1:26 by reading it in light of the Platonic text. He also gives a new monotheistic interpretation to the Platonic text:

And if so, also with regard to the form which it contains, those activities will be nobler than all the rest of the natural existents, although some of them are permanent, like the heavens and all their hosts, as it says [Deuteronomy 10:14-15]: "They belong to ha-Šem, your God: the heavens, and the highest heavens, the earth, and everything which is in it. Only to your fathers did ha-Shem have affection." Indeed, it says: "Let us make man," as though He was consulting His "familia," as [in the case of] the "words of our fathers" [i.e., the Rabbanan] of good memory. It seems that it teaches [us] that Godmay He be praised-decrees then that there will be the creation of this intellectual potency and its emanation on man
ואם כן גם מצד צורתו אשר בה תהיינה אותן

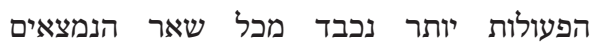

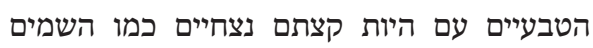
וכל צבאם כאמרו הן לה' אלהיך השמים ושמי נמים נמים נמים

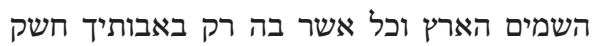
ה' אמנם באמרו נעשה אדם כנמלך בפמיל בפילי באבותיד

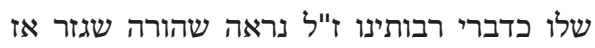

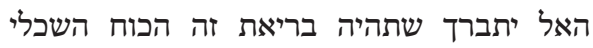
ושפעו באדם מאת משרתיו הנבדלים או מאריה מאחד השכלי

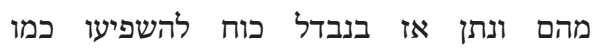

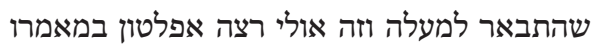
אשר הביא אבן רשד בביאור ספר מה שאחר אוזר אפלמון במארו

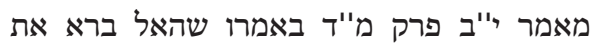

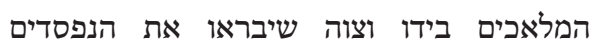
ונשאר הוא במנוחה בידום

quid immortale a fortiori quidem sequitur ut ipsa Dei imago his prestantior, habeat esse quid immortale."

47 Cf. Long Commentary on Metaphysics, 1653: "This has been explained by Nicolaos the Peripatetic in his book on the Metaphysics. This is why we see that the man who has attained this science has achieved the most perfect state of existence, and that it is the best of his actions because it is the action in which the best being shares. What is said on the authority of Plato's myth, namely that the creator created the angels himself and then entrusted them with the creation of mortal animals and remained himself idle and inactive is a myth which it is wrong to take as truth. It may be that such an imputation on the creator is the cause of the obligation of the Sabbath in the religion of the Jews."

48 Or 'Ammim, 101. 
from His separate servants or from one of them, and He gave [it] then in a separate potency to emanate it, as has become clear above. And this is perhaps what Plato wanted [to say] in his statement which Averroes mentioned in the commentary on Metaphysics 12, par. 44: "God created the angels by His hand and commanded that they create the corruptible things. And He stayed at rest.”

The same passage of the commentary on Metaphysics 12.44 is also presented in the eighth chapter of Light of the Nations, "On the Divine Unity":49

Et fortasse id voluit Plato in sermone ab Aven R. allegato in commento Metaphysicorum XII, 44 ubi dicit : "Hoc autem quod Plato dixit in suis verbis obscuris, quod Creator creavit angelos manu, deinde precepit eis creare alia mortalia et remansit ipse in quiete sine labore, non est intelligendus ad litteram etc." Et hoc fortasse putavit Plato ductum illa modernorum ratione ab Aven R. ibidem relata, qua scilicet dicitur quod: "Prima substantia habet esse una et simplex in fine, quoque ab uno et simplici non provenit nisi unum."50
ואולי זה רצה אפלטון במאמרו אשר הביא אבן

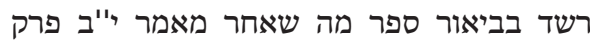
מ"ד באמרו אמנם זה שאמר אפלטון במאמריו

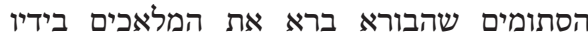
ואחר ציוה להם שיבראו ההווים ונפסדים ונשאר במים בידיו

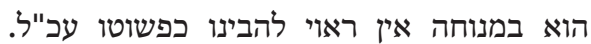

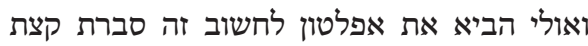

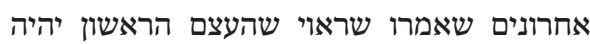

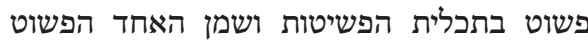

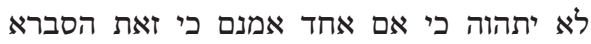
עם היותה בלתי מופתית אלא שהיא כיא כיא דעת אויצינא וזולתו מהאחרונים בלתי מתופתי
And this is probably what Plato wanted [to explain] in the speech which Averroes quoted in the commentary on Metaphysics 12.44, in which he says: "This is what Plato said in his obscure words: the creator created the angels by his hands, and afterwards he ordered them to create the mortal beings and he re-
And perhaps this is what Plato wanted [to explain] in his statement which Averroes mentions in the commentary on Metaphysics 12,44: "This is what Plato said in his obscure statements: the creator created the angels with His hands and afterwards He gave them the order that they should create the generable

49 Or 'Ammim, 59-64; Lumen Gentium, 45r [49]-47v [53].

50 Lumen Gentium, 46r [51].

51 Or 'Ammim, 62. 
mained at rest without working. It is not appropriate to understand this literally." And this is probably what Plato thought, according to what Averroes explains considering the position of some later philosophers saying that the first substance will be one and absolutely simple, because from one comes forth the one and the simple. and corruptible [things], and he remained at rest. It is not appropriate to understand this literally." And perhaps this brought Plato to consider the opinion of some later [philosophers] who said that it is appropriate that the first substance is absolutely simple, the simplicity, and that from a simple being nothing will be generated except [another] one. Yet this opinion is not demonstrative, but only the opinion of Avicenna, and, besides him, of other later [philosophers].

Sforno not only affirms that angels may be considered as the secondary gods (as in the Platonic tradition), but also that this vision is consistent with the account in Genesis. Hence, there is no contradiction between the Jewish tradition and the philosophical position, because the intellectual natures are emanated directly from the Creator.

Sforno uses the Platonic idea to interpret a biblical verse, since he quotes Plato (or better, the interpretation given by Averroes via Themistius) to clarify Genesis 1:26. In Or 'Ammim, Sforno quotes not only Genesis 1:26, but also Psalm 148:2-6, distinguishing the activities of men from the Divine actions and additionally the difference between men and angels:

And when it says "like our likeness," it makes known that there will be an agent [acting] by knowledge and consciousness. And therefore, it will be similar to God-may He be praised-and His angels. And it is not right that this will only happen naturally to the rest of the acting existents, because the likening will be by form. And the form is known by the activities which follow from it. But it says "like our likeness," together with the [letter] "Kaf" of the resemblance ["like"], to teach [us] that the likening is not [a] perfect [identity]. And this is so
ובאמרו כדמותנו הודיע שיהיה פועל בידיעה

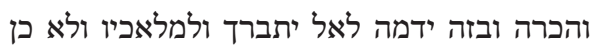

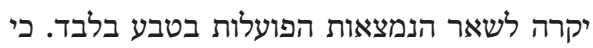
אמנם ההדמות יהיה בצורה והצות הפורה תמות בטותע בלעד. בפעולות הנמשכות ממנה אמנם אמר כדמותנו יהותות נורות עם כ"ף הפעלות הנמשכות להורות שמנה אמנם אהמות הוא בלתי כדמות שלם. וזה כי האדם הוא נבדל בפעולותיו בצד

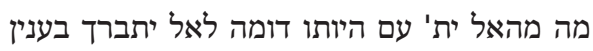
הבחירה. וזה כי בחירת האל יתברד עם היות דומה לאל יתברד בעולי לטוב כי אמנם הטוב יהיה מצד התכירת הכלית. והכרי היא לעולם אין תכלית יותר נכבד מהפקת הטוב יהיה מצד הונו יתברך אבל וכלית והנה

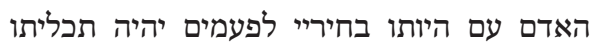

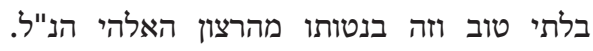
כאמרו הדרכי לא יתכנו בית ישראל הלאות הלאי הניל 
because man, by his activities, is separate in a certain way from God-may He be praised-although he is similar to God-may He be praised-in the case of free choice. And this is so because the free choice of God-may He be praised -is always for the good, because indeed, the good will be in accordance with the goal. And see: there is no nobler goal than the bringing out of His will-may He be praised. But man, although he also choses freely, sometimes has "a goal that is not good". And this is so because of his inclinations [to deviate] from the above-mentioned divine will, as it says [Ezekiel 18:29]: "Is my way not just, House of Israel? Is it not your ways that are unjust?" And in a certain way, he is separate from the angels because of his activities, although he is similar to them because he is an agent in knowledge and consciousness, because indeed, the activities of the angels, although they have knowledge and consciousness, are not freely chosen by them. And this is so because they are an eternally in act without the opposition of an appetitive faculty. Their activities will forever be right and the sin which occurs in the activities of man as caused by the appetitive [faculty] and the intellect neglecting to stand against [the state of] not forever being an intellect in act will not happen to them, as the poet testifies [Psalms 148:2, 6]: "Praise Him all His angels, etc."

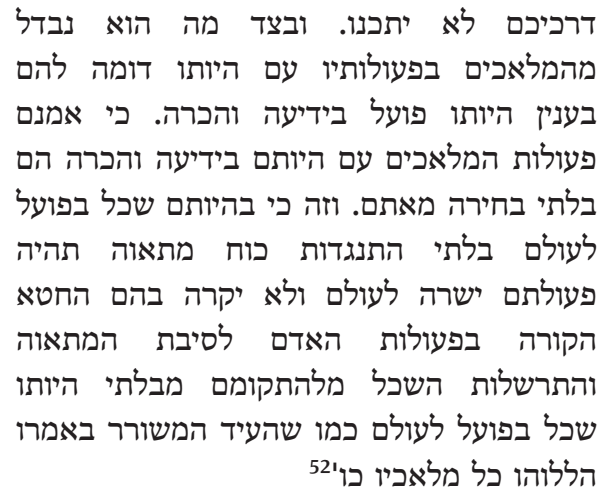

On the one hand, the angels are the separate intellects ${ }^{53}$ and the pure separate forms; on the other hand, men, who are similar to God and angels, sharing the intellectual 
soul with them, are superior to the latter, because human beings possess free will, which gives them a superior nature. ${ }^{54}$

In the Kitvei, Sforno shares the same ideas: God gave man an opening to acquire knowledge regarding entities that are separate from matter (i.e., angels) through the knowledge of our souls; for instance, the angels are substances separate from matter by definition:

In our image. [Who shall be] a substance that is everlasting [endowed with] reason; and thus God, the Blessed One, gave man an opening in His Torah to acquire knowledge regarding those separate from matter through the knowledge of our souls.

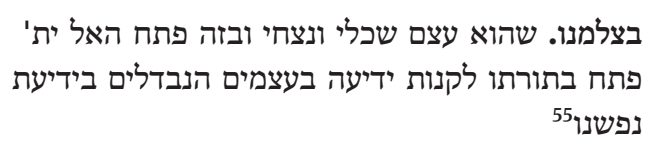
פתח בתורתו לקנות ידיעה בעצמים הנבדלים בידיעת ובוזי פתות הפות נפשנו55 בתור

Praise Him, all His angels, all substances which are separate from matter.

All His hosts, the stars. And both Sun and moon, whose actions are well-known, and after them

\author{
הללוהו כל־מלאכיו, כל שאר העצמים הנבדלים מחומר.

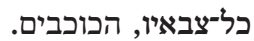 \\ ועל כולם כים נירו, \\ שמש וירח, שפעולתם יותר מפורסמת ואחריהם - כל- כולם \\ כוכבי אור \\ שמי השמים, הגלגלים שהם שמים בגובה גם בערך אל
}

of Creation (Cambridge: Cambridge University Press, 1994), particularly 142: “The classical Jewish philosophers identify them with the separate intellects of the astronomy of their time. In the case of the sages and Rashi, these substances, who are second in power and perfection only to God, turn out to be reified virtues."

54 On the imago Dei, cf. the studies of Warren Zev Harvey, particularly his lecture at the second international symposium.

55 Genesis 1:26.

56 Cf. Kitvei Rabbi Obadiah Sforno, ed. Ze'ev Gottlieb (Jerusalem: Mossad ha-Rav Kook, 1987), Genesis 1:6-7:

יהי רקיע בתוך המים - יהי טבע בתוך המים היסודיים כמו גלגל בתוכם סביב, מבדיל בצורה קצתם מקצתם, באופן

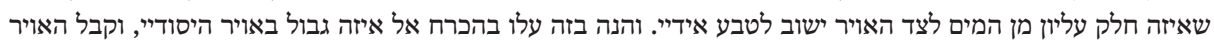

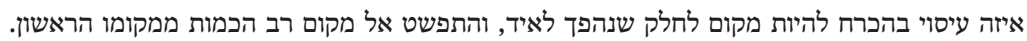

"Let the nature of the elemental waters become as though the form of a sphere is girdling it, separating one part from the other, in such manner that a portion of the upper waters adjacent to the air mass change once again to the nature of vapor, this air will now perforce somehow be made into a place for the portion of water which changed to vapor. It will expand considerably into a larger area than it was originally.”

ויעש אלהים את הרקיע - ובהיות שכאשר סרו קצת המים היסודיים מתחת אותו החלק מהם שנהפך לטבע אידיי,

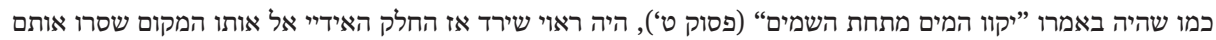

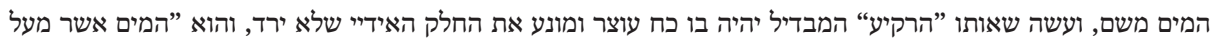




\section{all your stars of light.}

You heavens of the heavens, the

spheres which are the highest heav-

ens over the firmament are called heavens, and you waters above the heavens, the air [portion] of the waters which are the water above the firmament, He also established them forever and ever.

Let them praise the name of the Lord, which is the perfect Name.

For He commanded and they were created, He did not speak before. He also established them forever and ever, which are eternal and incorruptible forever.

\author{
הרקיע הנקרא שמים, והמים אשר מעל השמים, \\ האויר המימיי אשר הם המים, והמים אשר משל מעל לרים ליעים, \\ ויעמידם לעד לעולם

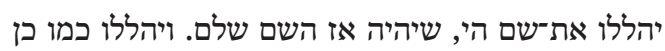

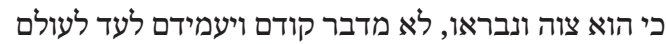 \\ שיהיו נצחיים בלתי נפסדים לעולם לארבי קובי
}

לרקיע", באופן שירד החלק האוירי המעוסה, ונשאר האידיי במקומו הראשון. ולזה בהגיע שם שם האיד הליד הלח, יתעבה ויוליד

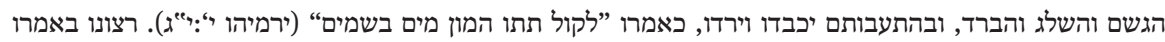

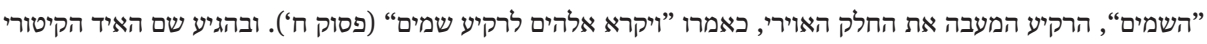

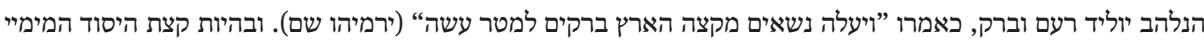

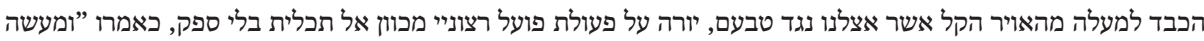

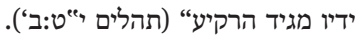

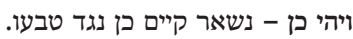

"Now, since the rest of the foundation waters-which remained below those waters that vaporize -gathered together, as it says, let the waters beneath the heaven be gathered, it should follow that the upper waters which became vapor would have filled the vacuum left by the departure of the waters. However, He made the firmament which separated (the higher and lower waters), in such manner that it was given the power of restraint, preventing the vapor portion-that is, the water which was above the firmament-from descending; in a manner that the fashioned atmosphere did fill the void while the vapor remained in its initial position. Now, when the moist vaporized water becomes dense, it brings forth rain, snow and hail as it becomes laden heavily (with water) and descends (to the earth), as it is said, 'at the sound of His placing an abundance of water in the heavens' (Jeremiah 10:13). What is meant by the term 'heavens': is the firmament which holds back the vapor portion, as it is said "And God called the firmament "heavens" (Genesis 1:8). And when the smokeladen mist comes there, it results in thunder and lightning, as it is said: 'He lifts up clouds from the ends of the earth, thunder from the rain He makes' (Jeremiah 10:13). Since the elemental waters, which are denser, are above the light air, this condition is contrary to nature, indicating that is an act performed by God's Will, directed without a doubt toward a purpose and end as it is said, "the work of His hands shall the firmament declare' (Psalms 19:2)."

57 Psalm 148:1-2. 
In the biblical verses, we find alternate explanations of the same philosophical concepts found in Light of the Nations. As in his philosophical work, Sforno considers the angels to be separate substances; they share their specific nature with the celestial bodies, similarly separate from matter. In his interpretation of the Psalm, Sforno focuses on the creation of the cosmos, i.e., the stars and the firmament, referring once again to Genesis 1:2 and 1:7, but also to On the Heavens 2:42. It is also interesting to note that Sforno uses a similar idea in $\mathrm{Or}$ 'Ammim. $^{58}$

And He provides the proof of this [Genesis 1:2]: "And the earth was Tohu and Bohu," that is to say: because the first form was necessarily in the prime matter specialised for it, and the composition of them was called "Tohu and Bohu." And from it, through change in different ways and in different parts of them, darkness, which is air deprived of light [ibid.], was generated "above the abyss," which is made up of the two heavy elements [i.e., earth and water], which are next to the centre. And he continues: "The spirit of God was hovering on the surface of the water," to convey elementary fire, that it was [generated] by the propulsion of a separate substance, moving and hovering over the darkness on the surface of the water, because the separate substances are called "the spirit of God," as told in the story of the work of creation [Psalms 104:4]: "He makes His angels spirits." And it testifies, if so, that He hovered over the air and move it on the water. And therefore, part of it became moist by its proximity to the water, and part of it (became) warm and dry, taking on a fiery form by its proximity to the sphere and its movement, as Aristotle explains the cause of elementary fire in $\mathrm{On}$ the Heavens 2.42.

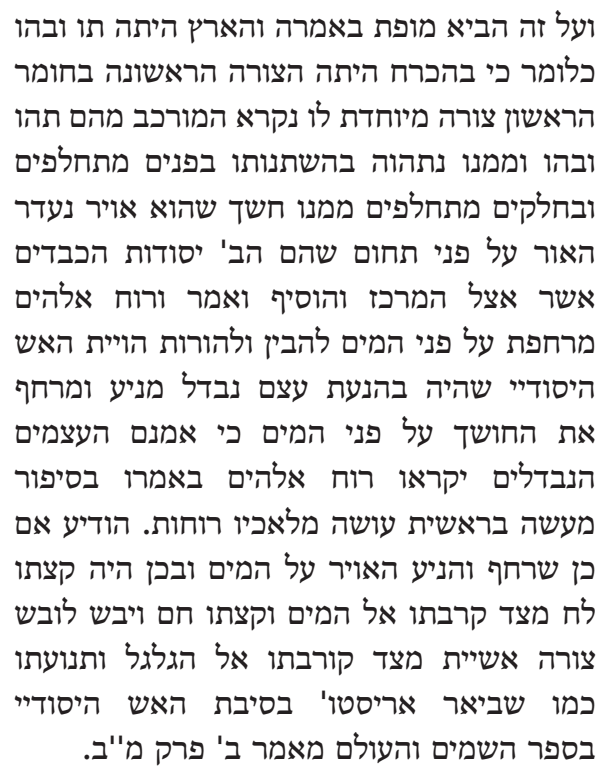

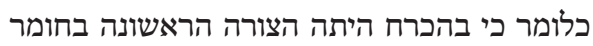

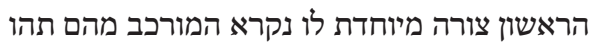

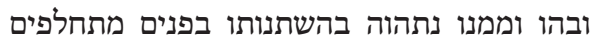
ובחלקים מתחלפים ממנו חשך שהוא אויר נעדר בתות בפנים מתום האור על פני תחום שהם הב' יסודות הכבדים משואים

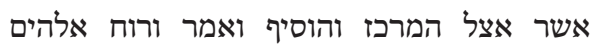

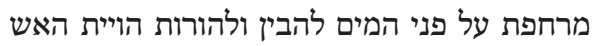

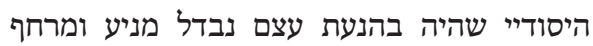

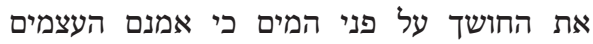
הנבדלים יקראו רוח אלהים פנים באמרו כים במני העיפור מעשה בראשית עושה מלאכיו רוחות. הודיע אם בסים ביפור

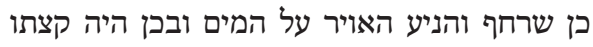

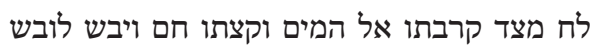
צורה אשיית מצד קורבתו אל המים וקצו הגל חם ותנועתו לובשו

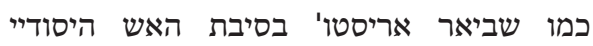
בספר השמים והעולם מאמר ב' פרק מ"ב. בסיבת המשי 
Sforno tries to harmonise philosophy and the Torah in a double sense: from one side, in his Kitvei, he gives some philosophical doctrines belonging to the Aristotelian tradition in order to explain the biblical verses. On the other, he concludes each chapter of his philosophical enquiry with a biblical verse to show that only with the light of the Torah ${ }^{59}$ is it possible to understand the ultimate end of the cosmos and of human beings:

But many beautiful words are found in the Holy Scripture which teach [us] great things about righteousness in ethics and politics to improve and orderly arrange both soul and body to turn them towards the [right] way. But it is good for those of clean hearts to present doubts, flaming arrows which disturb [us] and cause sorrow to the soul, at the beginning of the inquiry and to overwhelm them all with pure words and with clear arguments about all that is mysterious. These [words] are for the life of the [future] world. They bring forth justice in truth. This shall be told about ha-Shem to the [coming] generation.

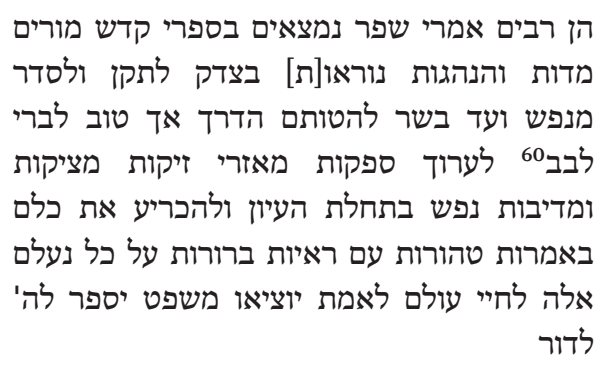

\section{Bibliography}

\section{Primary Sources}

Aquinas, Thomas. Aristotle's De Anima in the Version of William of Moerbeke and the Commentary of St. Thomas Aquinas. Translated by Kenelm Foster and Sylvester Humphries. Reprint ed. New Haven: Yale University Press, 1959.

Averroes. Aristotelis Metaphysicorum libri XIIII. Cum Averrois Cordubensis in eosdem commentariis et epitome Theophrasti metaphysicorum liber. Venice: s.n. 1552.

Averroes. Aristotelis Physica, De celo et mundo, De generatione et corruptione, De anima, De sensu et sensato, De memoria et reminiscentia, De somno et vigilia, De longitudine et brevitate vitae, De meteoris, cum Averrois Cordubensis expositionibus; Liber Averrois de substantia orbis. Translated by Michael Scotus. Venice: s.n. 1473.

59 Or 'Ammim, 9.

60 As Harvey suggests, this is an implicit reference to Psalm 73:1 ("Surely God is good to Israel, even to such as are pure in heart”) and Isaiah 50:11. 
Averroes. Destructio destructionum philosophiae Algazelis. Agostino Nifo. Venice, s.n. 1497.

Averroes. Ibn Rushd's Metaphysics: A Translation with Introduction of Ibn Rushd's Commentary on Aristotle's Metaphysics, Book Lām. Edited by Charles Genequand. Leiden: Brill 1984.

Ebreo, Leone. Dialoghi d'amore di Maestro Leone Medico Hebreo. Rome: per Antonio Blado d'Assola, 1535.

Gersonides (Levi ben Gershom). The Wars of the Lord. Translated by Seymour Feldman. 3 vols. Philadelphia: Jewish Publication Society, 1984-99.

Maimonides, Moses. The Guide of the Perplexed. Translated by Shlomo Pines. 2 vols. Chicago and London: University of Chicago Press, 1963-78.

Nifo, Agostino. Commentationes in librum Averrois de Substantia Orbis. Venice, s.n.1508.

Pico della Mirandola, Giovanni. Conclusiones sive Theses DCCCC: Romae anno 1486 publice Disputandae, sed non admissae. Edited by Bohdan Kieszkowski. Geneva: Droz, 1973.

Sforno, Obadiah. Kitvei Rabi Obadiah Sforno. Edited by Ze'ev Gottlieb. Jerusalem: Mossad ha-Rav Kook, 1987.

Sforno, Obadiah. Commentary on the Torah. Translated by Raphael Pellcovitz. Brooklyn, New York: Mesorah Publications, 1997.

Sforno, Obadiah. Lumen Gentium. Bologna, s.n. 1548.

Sforno, Obadiah. Or 'Ammim. Bologna, s.n. 1537.

Themistius. On Aristotle On the Soul. Translated by Robert B. Todd. Paperback ed. London: Bloomsbury, 2014.

\section{Secondary Sources}

Akasoy, Anna, and Guido Giglioni, eds. Renaissance Averroism and Its Aftermath: Arabic Philosophy in Early Modern Europe. Dordrecht: Springer, 2013.

Bonfil, Robert: "Il Rinascimento: la produzione esegetica di 'O. Servadio Sforno." In La lettura ebraica delle Scritture, edited by Sergio J. Sierra, 261-77. Bologna: EDB, 1995.

Bonfil, Robert. "The Doctrine of the Soul and Holiness in the Teachings of Obadia Sforno." [Hebrew.] Eshel Beer Sheva 1 (1976): 200-257.

Frank, Daniel H., Oliver Leaman, and Charles H. Manekin, eds. The Jewish Philosophy Reader. New York: Routledge, 2000.

Harvey, Warren Zev. "Maimonides' First Commandment, Physics, and Doubt." In Hazon Nahum: Studies in Jewish Law, Thought, and History Presented to Dr. Norman Lamm, edited by Yaakov Elman and Jeffrey S. Gurock, 149-62. New York: Michael Scharf Publication Trust of the Yeshiva University Press; Hoboken, NJ: Ktav, 1997.

Meyrav, Yoav. "Spontaneous Generation and Its Metaphysics in Themistius' Paraphrase of Aristotle's Metaphysics 12." In Aristotle Re-Interpreted. New Findings on Seven Hundred Years of the Ancient Commentators, edited by Richard Sorabji, 195-210. London and New York: Bloomsbury Academic, 2016.

Montada, Josep Puig. "Eliahu del Medigo, the Last Averroist." In Exchange and Transmission across Cultural Boundaries: Philosophy, Mysticism and Science in the Mediterranean World, edited by Haggai Ben-Shammai, Shaul Shaked, and Sarah Stroumsa, 155-86. Jerusalem: Israel Academy of Sciences and Humanities, 2013.

Nardi, Bruno. Studi su Pietro Pomponazzi. Florence: Le Monnier, 1965.

Roth, Cecil. The Jews in the Renaissance. Philadelphia: Jewish Publication Society, 1959.

Samuelson, Norbert M. Judaism and the Doctrine of Creation. Cambridge: Cambridge University Press, 1994.

Veltri, Giuseppe. Alienated Wisdom: Enquiry into Jewish Philosophy and Scepticism. Berlin and Boston: De Gruyter, 2018. 
Zonta, Mauro. Hebrew Scholasticism in the Fifteenth Century. A History and Source Book. Dordrecht: Springer, 2006.

Zonta, Mauro. "The Autumn of Medieval Jewish Philosophy: Latin Scholasticism in 15th-Century Hebrew Philosophical Literature." In "Herbst des Mittelalters"? Fragen zur Bewertung des 14. und 15. Jahrhunderts, edited by Jan Aertsen and Martin Pickavé, 474-92. Berlin and New York: De Gruyter, 2004. 